Information for citation:

Shchennikova L.V. Pravo veshchnykh vydach v kriteriyakh otsenki nemetskikh tsivilistov veshchnykh obremeneniy [The Right of Real Issues in German Civilians' Evaluation Criteria for Real Encumbrances]. Vestnik Permskogo Universiteta. Juridicheskie Nauki - Perm University Herald. Juridical Sciences. 2016. Issue 34. Pp. 461466. (In Russ.). DOI: 10.17072/1995-4190-2016-34-461-466.

UDC 347.2

DOI: $10.17072 / 1995-4190-2016-34-461-466$

\title{
THE RIGHT OF REAL ISSUES IN GERMAN CIVILIANS' EVALUATION CRITERIA FOR REAL ENCUMBRANCES
}

\section{V. Shchennikova}

Kuban State University

149, Stavropolskaya st., Krasnodar, 350040, Russia

ORCID: 0000-0002-1972-2287

Researcher ID: H-3447-2016

e-mail: civil_law402@mail.ru

Introduction: the author of the article believes that development of the system of corporeal rights in Russia, its replenishment with new types, including the rights of real issues, requires preliminary scientific study in the aspect of the domestic civil law. Purpose: based on works by German civilians, to show that an analogue of the right of real issues, namely, real encumbrances, neither fits into the traditional classification of the corporeal rights, nor corresponds to "an ideal image" of the corporeal right. In this connection, the German legislator was "sceptic" about them, though they were not excluded from the contents of the German Civil Code. Methods: methodological framework of the research comprises a set of general and specific scientific methods of cognition, with the comparative and legal method being the main one. Results: based on the analysis of German civil doctrine, it is shown that the legal nature of real encumbrances is debatable, economic significance is not considerable, and the scope of application tends to decrease. It is reasoned that real encumbrances in Germany and, respectively, the right of real issue in Russia can be used mainly as a method to ensure support for an aged family member. Conclusions: as the scope of the right of real issues application is rather narrow, regulations of this institute shall have an evident social focus, providing a proprietary mechanism to protect the rights and interests of persons receiving property provision.

Keywords: civil law; corporeal right; real encumbrances; right of real issues

\section{Information on Russian}

\section{ПРАВО ВЕЩНЫХ ВЫДАЧ В КРИТЕРИЯХ ОЦЕНКИ НЕМЕЦКИХ ЦИВИЛИСТОВ ВЕЩНЫХ ОБРЕМЕНЕНИЙ}

\author{
Л. В. Щенникова \\ Доктор юридических наук, профессор, зав. кафедрой гражданского права \\ Кубанский государственный университет \\ 350040, Россия, г. Краснодар, ул. Ставропольская, 149 \\ ORCID: 0000-0002-1972-2287 \\ ResearcherID: H-3447-2016 \\ e-mail: civil_law402@mail.ru \\ (C) Shchennikova L. V., 2016
}


Введение: автор статьи полагает, что развитие системы вещных прав в России, включение в нее новых видов, в том числе права вещных выдач, требует предварительной научной проработки со стороны отечественной ичивилистики. Цель: показать, опираясь на труды немецких иивилистов, что аналог права вещных выдач, а именно вещные обременения, не вписываются в привычную классификацию вещных прав, не подходят под «идеальный образ» вещного права, в связи с чем немеикий законодатель был настроен к ним «скептически», хотя и не исключил из содержания Германского гражданского уложения. Методы: методологическую основу исследования составила совокупность общенаучных и частнонаучных методов познания, основным из которых является сравнительно-правовой. Результаты: на основе анализа немецкой цивилистической доктрины показано, что юридическая природа вещных обременений дискуссионна, экономическое значение не велико, а сфера применения имеет тенденцию к сужению. Аргументировано, что вещные обременения в Германии и, соответственно, право вещной выдачи в России могут быть использованы главным образом как способ обеспечения содержания престарелому члену семьи. Выводы: поскольку сфера применения права вещных выдач достаточно узка, то нормы этого института должны иметь ярко выраженную сочиальную направленность, обеспечивая вещно-правовым механизмом защиту прав и интересов лии, получающих имущественное предоставление.

Ключевые слова: гражданское право; вещное право; вещные обременения; право вещных выдач

\section{Introduction}

A hard task it is to make civil laws. At the beginning of the $19^{\text {th }}$ century, this was particularly obvious for Mr. S. S. Speranskiy who was to assess the decennial work of the Law-Drafting Committee. His review proved most unfavorable. Mr. S. S. Speranskiy failed to find in the given material those "two-or-three substantial words" urgently required for the right of property. His contemporaries used to be fond of a joke that not for nothing the signboard over the Committee gates lacked the first "C". Thus, laws turned out not to be drawn up, that is, to represent something new, but were left as they were, in their former, unaltered and, in general, conventional form [1]. Today the alleged developers of the Civil Code in draft have an opportunity to appraise the innovations of the property law. A pause taken by the legislator to improve the proprietary regulation is deemed useful to analyze once again the results of the work done. It is important to consider the degree of reasonableness of the new pattern in order to find out what is hidden behind the related "twoor-three" words.

In the current research, the pattern of the rights of real issues is of particular interest since it is essentially new for the proprietary law of Russia. It is presented by the authors of the draft law in
Art. 305-305.6. The analysis of this new for the Russian civil legislation kind of proprietary law will be performed in accordance with the groundwork of the German civil law with respect to its prototype, that is, real burden.

\section{Basic Provisions of the Civil Code Draft Law on the Right of Real Issues}

In the draft of the second division of the Civil Code, under the right of real issue is understood the possibility for the holder to occasionally receive the advancement in the form of goods, money, works and services in the specified rate (volume) from the owner of the real estate, and in case of failure to receive such advancement, an authority to dispose of such a res by means of execution upon the property in accordance with the procedure stipulated for mortgage (see Art. 305 of Civil Code in draft). The main ground for the right of real issues to arise is a special real contract named the contract of establishing the right of real issues (see Cl. 4 Art. 305 of Civil Code in draft). The essence of the contract is the rate (or volume) of the advancement, its pecuniary valuation, the periodicity and the period of validity of the right $(\mathrm{Cl} .1$ Art. 305.1 of Civil Code in draft). Within the civil regulation, there is quite a number of prohibitions set by the law drafters. For instance, the advancement in 
compliance with Cl. 3 Art. 3051 of the Civil Code may not give the example of the real estate usage burdened with such a right. The endurance of the right may not exceed 100 years. The advancement in cash may not be substituted by its any other form (see Cl. 1 Art. 305.1 of the Civil Code in draft). The rate of the advancement may not be reconsidered more frequently than once a decade. In case of the infringement of the obligation as to the advancement, Art. 305.5 of the law in draft initially offers to set the obligatory law consequences. Only in case of the repeated commission of nonfulfillment, there is a possibility of the proprietary consequences application in form of the execution upon the burdened real thing.

\section{The Questions that Require Preliminary Scientific Study with respect to the Right of Real Issues Pattern}

Is everything definite and obvious enough in the provisions devoted to the right of real issues formulated for enactment by the Russian legislator? Not at all.

On the contrary, though the size of the scope of the proprietary regulation is moderate, just seven articles of the Civil Code, their meaning gives rise to a set of questions that require preliminary settlement. Doubts arise as to the proprietary nature of the proposed pattern. The definition "advancement" has always been a feature of obligation. 1. Shall this word, used in the right of real issues meaning, not give the rise to deem its legal nature as solely obligatory? 2. Suppose this right is acknowledged a proprietary one - what shall be the main indication to prove its proprietary nature? 3 . Is it possible to consider this right as a combined one representing a cross between the obligation and a proprietary law? Shall it not be a hint as to the so-called "intervening" responsibility for the infringement of the obligation connected with the advancement proved to combine the obligation and proprietary law inauspicious effects? 4 . What is the right of real issues and the right of property correlation? Is it possible to deem this right as some modification of the right of property with a suspensive condition in case of nonfulfillment or improper fulfilment of the advancement obligation? 5 . What are the historical roots of this right? May it be considered a universal pattern, clearly indispensable for any of the contemporary law order or is it a product of exclusively its epoch brought into by quite certain causes of the given state? 6 . What ownership relations shall this right be mainly applied to? What may the interest of the participants of the civil circulation in its application be seen in? 7. The doubts are connected with the imperative prohibition of the reconsideration of the advancement rate more frequently than once a decade. And what to do with the inflation processes, rising prices and financial crises? Why is it so that instead of the index provision there is a prohibition to any amendments to the rate of advancement over the course of a decade? 8 . The right is patterned as having solely fixed-dated nature, whereas one of the attributes of the generic category is precisely the absence of a particular predetermined time-limited term? 9. What causes the prohibition of the substitution of the advancement in cash for any other form of the advancement, for instance, in kind? What is such a prohibition stipulated with? To what extent does it correlate with the principles of equality of the civil law participants, justice and fidelity? 10. Certain doubt is caused by the provision stipulating liability for nonfulfillment of the obligation for the advancement proposed by the legislators. To what extent does it correlate with the nature of the law in question and its position in the system of the interest in real property?

Let us try to find the answers to the given questions with the help of teaching of German civilians such as Jens Thomas Füller, Leopold Mann, Hans Carl Nipperdey, Klaus Bernhard Gablenz, Wolfgang Brehm, Christian Berger, Horst Heinrich Jakobs, Werner Schubert, Dietrich Joswig, Friedrich Mattern and Siegfried Rafle, who studied the problem of the real burden. The study of works by the authors mentioned was of quite interest, though it was a little complicated due to the required work with literature in the original language. Let us focus our attention on the most significant conclusions drawn by the German civilians listed.

\section{German Civil Law about the Real Burden}

Jens Thomas Füller in his study «Eigenständiges Sachenrecht» discovered the roots of the real burden in the German medieval law. The scholar considered the legal regulation of the relations arising out of the real burden fragmentary. This author called the systematic classification inherent in the prevailing property law very disputable. J. Füller emphasized that the real burden "failed to correspond to the ideal image of the property law". He considered that the ancient theories classified this law as the "obligatory legal structure in 
which the debtor is stipulated through the instrumentality of the proprietary on the estate" not by accident. J. Füller gave numerous opinions concerning the legal nature of the real burden. However, he thought that the result of the discussion would not matter and as a result of his analysis he called the real burden an obligatory claim that has an absolute impact [2].

In his study «Das Institut der Reallasten auf deutschen Bauerngütern», Schwartz finds the source of real burden in Ancient Rome. He puts emphasis on the fact that the real burden is predominantly a peasants' obligation. According to this scholar, the true nature of this law is hard to be found, taking into account so many diverse views; and it is even more difficult to suggest one's own. I. Schwartz determines the essence of real burden with the formula as follows. Here, the real owner cedes the partial guarantee on the immovable property and stipulates his own right on the specified payments [8].

H. Westermann in his «Sachenrecht: ein Lehrbuch» claims real burden has played an important role as it represented "versatile obligation of the land to the raising and service rendering". $\mathrm{H}$. Westermann considered that as the real burden develops it has an increasingly "palsy influence on the economy". At the same time, the scholar considered the advantage of real burden in comparison with the mortgage because of its "considerable flexibility" and adaptivity. H. Westermann claims that the legal essence of real burden is disputable and emphasizes that it shall not be called an "indirect accommodation right" for it is not allowed to harvest the production from the estate. $\mathrm{H}$. Westermann in his research calls the real burden "an exceptionally real right to regular payments". The author claims that this right is negatorily protected. Moreover, the corporeal claim is met in the course of the forced selling up of the estate or any other real estate. The main case of real burden application, according to the author, is facility rendering to the aged family members. The scholar depicts a specific situation in which Peasant B., using the pattern of real burden cedes his estate to his son, who in his turn undertakes an obligation to give cash allowance of a specified rate [7].
G. Berger in his book «Sachenrecht» calls the studied pattern in question a proprietary secured interest supplemented with a personal responsibility, which gives a possibility to bring an action against the proprietor. This author places emphasis on the controversy of real burden in comparison with other forms of the limited proprietary interest, which is why this interest is defined on the one hand as the law of property and obligation and on the other hand as a proprietary-protected obligation. As is accentuated by G. Berger, the legislators when adopting the German Civil Code were quite sceptic about the real burden subject to the economic reasons but failed to abolish this norm. That is the reason why the land legislators were given the possibility to regulate real burden. G. Berger describes the scope of the real burden application at the local level separately from the German Civil Code and even rules out its reestablishment considering that to possibly be the title to the living allotment to the aged family member. Moreover, according to this author, the real burden applications appeared to be a guarantee of the right to the energy penance as well as an obligation to structure maintenance. The author believes the real burden causes the proprietor to bear full property accountability for the particular payments obligation claim [6].

In his «Das Bürgerliche Gesetzbuch mit besonderer Berücksichtigung der Rechtsprechung des Reichsgerichts und des Bundesgerichtshofes» study, Friedrich Mattern calls the real burden "an external economic way" to have an influence upon the civil relations participants which objectively does harm to "the land and soil integrity". This author outlines the main real burden designation. He emphasizes that from time immemorial among villagers it was common that when rendering an agricultural enterprise over to the following generation an aged family member was given pecuniary payments and diverse services in return. Under the author's observation, the peculiarities of the real burden as a legal civil right are in the regularity of these payments and in the active policy orientation [9].

Klaus Bernhard Gablenz in his "Grundstückswerter-mittlung für Praktiker: Bewertung nach ImmoWert" study deems real burden as the main 
real right to be considered a right implementation. The author considered the essence of real burden in the proprietor's obligation to make regular contractually stipulated payments. He formulates the definition of burden as follows: "real burden is a private-law burden of the estate in compliance with which a proprietor is obligated to make contractually stipulated payments". The author speculates about the significance of the term in the real burden and outlines that this term may be set and may be not. As for the rent size, in the author's opinion, "the giver's financial possibilities and the taker's needs are to be correlated". The scholar outlines the necessity of the index clause which allows for altering the sum of the debt in connection with the "price for gold", "standard of life" or salary changes for some particular group of employees [5].

Hans Carl Nipperdey in his "Das deutsche Privatrecht in der Mitte des 20. Jahrhunderts: Festschrift für Hein-rich Lehmann zum 80 " study sees a considerable resemblance of real burden with the charging lien. He outlined that the real right in case of real burden should be incorporated in the lien category notwithstanding the fact that the law fails to denote it per se. The author claims that an emerging "breach" because of that shall be filled by means of applying the analogy of the estate lien [3].

Leopold Mann offers quite a peculiar concept of real burden in his "Untersuchungen über den Begriff der Reallasten im gemeinen Recht". This author reasons as follows. Real burden is not a real right as it does not involve the required authority. It is not a right of obligation either since it is not regulated by the obligation legal rules. This right cannot represent the proprietary right of obligation because such right does not exist. "What kind of structure is that?" - asks the author and responds to that question in the following way: "a person authorized to real burden receives "a conditional property ownership" as to the burdened estate which becomes absolute on condition that no payments are made". L. Mann supports his theoretical conclusion with a practical example. Here is what he writes: "A nominal quantity of fruit payment was to be made from the estate, however, it failed to be paid on time. As a result - the proprietor lost his title." All things considered, under L. Mann's concept, payment in real burden is made not to execute one's duty but to reserve the condition for the title. In the scholar's opinion, the real burden institution has "absolute German origins". Reasoning about the legal character of the real burden, the scholar claims it difficult to ascertain as it exists in the civil legislation in "an unbearably maimed" form. What made the scientist doubt the belonging of the real burden to the real right category? The thing is, in his opinion, that the real right, as a generic category, hardly corresponds to vast expanse for the variations; "it can be looked at this way and that way", still, there will by no means appear any new authority to be included in the law of property. And as the proprietor of the thing in case of real burden is not obliged to the action which would give him an authority to exploit, correspondingly, there cannot be a right with such a meaning, according to L. Mann [4].

\section{Conclusion}

All things considered, the analysis of German scientific literature on civil law enables us to formulate the following findings, essential for the consecutive development of the Russian real right legislation.

1. The real right nature of real burden is not clear. It is given a special place in the immovable property civil law system. It falls beyond the prevalent classification of rights and falls short of "the ideal image" of a real right.

2. Real burden cannot be referred to the "custom-patterned" real right. The principal feature to define its real right nature is the right to implementation. This feature gives a common ground for real burden and lien.

3 . The correlation between the right of real issues and the right of property is of particular interest. This correlation should be kept in mind by the legislator when regulating the consequences of nonpayment of the questioned sums. The proprietary right is "conditionally-natured" here, and to exercise the right timely payments are prerequisite.

4. The right of real issues has no Russian origins. It originates in the medieval German law. Thus, this civil law pattern was a product of a particular epoch, brought to life due to a certain economic environment in a particular state.

5. The legal regulation of real burden has always been a difficult task. Not coincidentally, the 
German legislator incorporated real burden into the codified civil legislation with cautiousness and stipulations.

6. The scope of the real burden application in Germany did not use to be wide, and as time went by it narrowed up to the aged family member upkeep regulation in the rural area, with land lots being items of immovable property.

7. The aim of the pattern connected with the upkeep of the aged family member required his interest protection including the form and the rate of the advancement. German scholars write about the necessity of indexation of payments. That is why the prohibitions in the right of real issues concerning the substitution of the pecuniary advancement by that in kind or impossibility to adjust the rate of the advancement more frequently than once a decade as proposed by the developers of the Civil Code in draft are inappropriate and fail to meet the justice and humane principles.

8. The term in the right of real issues is not much of a difference as it may be determined or may not.

9. The responsibility for nonfulfillment of the advancement obligation must have a real right nature that is to consist in the particular property title loss.

Thus, the incorporation of the right of real issues pattern into the Russian legislation requires a profound preliminary scientific study. The Russian legislator, taking into account the results of the analysis, has to decide whether the given civil law pattern is that necessary in modern civil law relations.

\section{References}

1. Korf M. A. Vosshestvie na prestol Imperatora Nikolaja I. Zhizn' grafa Speranskogo [The Accession to the Throne of Emperor Nicholas I. The Life of Count Speransky]. Moscow, 2015. 623 p. (In Russ.).

2. Brehm W., Berger C. Sachenrecht. 2006. Pp. 331-335. (In Ger.).

3. Füller J. T. Eigenständiges Sachenrecht. 2006. Pp. 74-75. (In Ger.).

4. Gablenz K. B. Grundstückswertermittlung für Praktiker: Bewertung nach ImmoWert. 2014. Pp. 296-300. (In Ger.).

5. Jakobs H. H., Schubert W. Die beratung des burgerlichen gesetzbuchs in systematischer $\mathrm{Zu}-$ sammenstellung der unveroffentlichten Quellen. Einführungsgesetz zum Bürgerlichen Gesetzbuch und Nebengesetze: (Zivilprozessordnung, Konkursordnung und Gesetz über die
Angelegenheiten der freiwilligen Gerichtsbarkeit). 1990. Pp. 372-400. (In Ger.).

6. Joswig D., Mattern F., Räfle S. Das Bürgerliche Gesetzbuch mit besonderer Berücksichtigung der Rechtsprechung des Reichsgerichts und des Bundesgerichtshofes. Kommentar. 1996. Pp. 59-87. (In Ger.).

7. Mann L. Untersuchungen über den Begriff der Reallasten im gemeinen Recht. 1872. Pp. 1-12; Pp. 17-21; Pp. 42-76. (In Ger.).

8. Nipperdey H. C. Das deutsche Privatrecht in der Mitte des 20. Jahrhunderts: Festschrift für Heinrich Lehmann zum 80. Geburtstag. 1956. Pp. 384-387. (In Ger.).

9. Westermann H., Gursky K.-H., Eickmann D. Sachenrecht: ein Lehrbuch. 1998. Pp. 870-877. (In Ger.).

10. Schwarz I. C. Das Institut der Reallasten auf deutschen Bauerngütern. 1827. Pp. 32-73. (In Ger.).

\section{References in Russian}

1. Корф M. А. Восшествие на престол Императора Николая І. Жизнь графа Сперанского. М.: Статут, 2015. 623 c.

2. Brehm W., Berger C. Sachenrecht. 2006. S. 331-335.

3. Füller J. T. Eigenständiges Sachenrecht. 2006. S. 74-75.

4. Gablenz K. B. Grundstückswertermittlung für Praktiker: Bewertung nach ImmoWert. 2014. S. 296-300.

5. Jakobs H. H., Schubert W. Die beratung des burgerlichen gesetzbuchs in systematischer $\mathrm{Zu}-$ sammenstellung der unveroffentlichten Quellen. Einführungsgesetz zum Bürgerlichen Gesetzbuch und Nebengesetze: (Zivilprozessordnung, Konkursordnung und Gesetz über die Angelegenheiten der freiwilligen Gerichtsbarkeit). 1990. S. 372-400.

6. Joswig D., Mattern F., Räfle S. Das Bürgerliche Gesetzbuch mit besonderer Berücksichtigung der Rechtsprechung des Reichsgerichts und des Bundesgerichtshofes. Kommentar. 1996. S. 59-87.

7. Mann L. Untersuchungen über den Begriff der Reallasten im gemeinen Recht. 1872. S. 1-12; S. 17-21; S. 42-76.

8. Nipperdey H. C. Das deutsche Privatrecht in der Mitte des 20. Jahrhunderts: Festschrift für Heinrich Lehmann zum 80. Geburtstag. 1956. S. 384-387.

9. Westermann H., Gursky K.-H., Eickmann D. Sachenrecht: ein Lehrbuch. 1998. S. 870-877.

11. Schwarz I. C. Das Institut der Reallasten auf deutschen Bauerngütern. 1827. S. 32-73. 